\title{
Seal Siberis Baikali taga
}

\section{Ell Vahtramäe}

Meid oli kolm: Anu Korb, Indrek Kaimer ja mina, Ell Vahtramäe. Me olime loksunud rongiga kõva kolm päeva ja jõudnud Omski oblastisse. Oli 30. aprill 1995 ja ees ootas kolm nädalat eesti asundustes. Pika teekonna olime ette võtnud, et näha, kuidas Siberis elatakse, mida on siinsed eestlased teistelt õppinud ja milliseid pärimusi oma esivanematelt talletanud, ühesõnaga- olime rahvaluuleekspeditsioonil.

Meiega oli kaasas nähtamatu hea vaim, kes korraldas meie

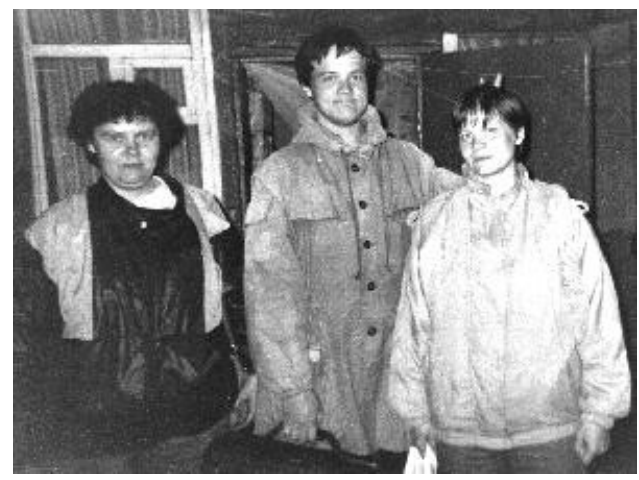
käike nii, et kõik sujus suurepäraselt. Me jõudsime igale poole õigel ajal ja ei pidanud külast külla sõitudele liialt oma aega ega närve kulutama.

Kokku viibisime neljas algselt eesti külas, millest nüüdseks on saanud tõeline paabel: seal elab eestlasi, venelasi, sakslasi, lätlasi, soomlasi, kirgiise, kasahhe, tatarlasi ja kõikvõimalikke muid rahvaid. Umbkaudu viiendik elanikkonnast ongi veel eestlased, seda vene statistika andmetel, kus sageli loetakse venelasteks kõik segaabieludest sündinud lapsed, ka need, kelle kumbki vanem pole venelane. Nii võivad olla venelastena kirjas näiteks eestlase ja lätlase järglased. Eesti keelt räägivad veel ainult vanema põlve esindajad, nende lapsed saavad aru, kuid ei oska oma emakeeles vastu kosta ja lapselapsed ei valda üldse eesti keelt. Esivanemate keele hääbumise põhjuseks peavad asjaosalised ise emakeelse koolihariduse puudumist. Eesti koole on Siberis olnud, kuid 1930. aastatel hakati neis ainult vene keeli õpetama. Pedagoogid olid endiselt eestlased, kuid nad ei tohtinud lastele emakeelset haridust anda. Raamatudki, mis ei olnud vene keeles kirjutatud, olid keelatud. Partei ja valitsuse targal juhtimisel on hoolega segatud rahvuslikku koosseisu. Varem polnud asundustes teisi rahvaid, vähesel määral käidi läbi vaid samausulistega, s.o. põhiliselt lätlaste, sakslaste ja soomlastega. Juhanna Parts Zolotaja Nivast kurtis: Enne olid eestlased ise. Küla oli kultuurne, inimesed elasid sõbralikult. Nagu venelastega segi segati, on kõik raisku läind.

Nõukogude valitsus hoolitses, et keegi ei tunneks end oma asupaigaga liialt seotud olevat, elanikke asustati pidevalt ümber. Näiteks Semjonovkas küüditati kogu küla soo taha, kuna seal küsimusele: Kes teil siin halvasti töötavad? vastati: Kõik on tublid töömehed.

Nüüdseks on asjad niikaugel, et eesti keel, meel ja kultuur on omadega ilmselt loojangule jõudnud. Kümne-kahekümne aasta pärast seal vaevalt et eesti keelt kuuleb, seega on ekspeditsioonideks selle rahvakillu juurde viimane aeg. Zolotaja Nivas naljatati: Varem öeldi, et siin on malenkaja Estonia, a nü̈̈, et malenki Berliin. Nimelt on sellesse külla viimasel ajal elama asunud palju sakslasi.

Zolotaja Niva ja Semjonovka on Eestist väljarännanute külad, nende asukate esivanemad tulid siia maad saama. Ivanovka ja Kovaljova on asutatud tsaariajal Eestist väljasaadetute poolt. Ükskõik, mis põhjusil on praeguste elanike esivanemad kunagi Siberisse asunud, nende järglased on kõik 
oma elupaigaga rahul: Meil siin on kõige parem kotus: pole sõdasid, maavärinaid, üleujutusi ega midagi. Ja maa on ka hea, puhas muld. Teil seal Eestis on põllud kõik kive täis, korjad ära, uued kasvavad kohe maa seest peale. Kuidas sa sellist harid või mis saaki sealt saad...Meil, mis maha paned, kõik kasvab. Nii on see siiani olnud, aga küsitav, kas see nii ka jääb, sest omad hädad on sealgi. Tõeliseks nuhtluseks on sool ja vesi, millega varem pole probleeme olnud, kuid mis mõtlematu inimtegevuse tagajärjel on maa peale tulnud. Maapinnal olid suured valged laigud, meile algul arusaamatu nähtus. Inimesed selgitasid, et see on sool. Selliste soolakute peal on võimatu midagi kasvatada. Nägime ka laiu vetevälju, mille tekkepõhjuseks pidasime algul soomaad ja noort kevadet, aga selgus, et varem pole neil põldudel kunagi vett olnud. Masendava mulje jätsid kuivanud kaasikud, kus kõivudest olid alles ainult valendavad tüved. Elanike sõnul olid puud kuivama hakanud umbes viis aastat tagasi ja põhjuseks peeti pealetungivat solonetsi. Kõige selle taga on looduse saastatus. Siberi tuumakatsetuste üks asupaik, Semipalatinski polügon jäi meie poolt külastatud paikadest vaid mõnesaja kilomeetri kaugusele. Oma osa on kindlasti ka uue kuivendussüsteemi juurutamisel.

Meisse suhtuti kui kallitesse külalistesse kunagi. Oodati, et me kõikidesse peredesse jõuaksime ja tingimata kõik kolm korraga. Teised olid meie pärast eestlastele natuke kadedad; üks ukrainlane käis noomimas, miks me ainult eestlaste juures käime, kui külas on veel teisigi rahvaid.

Eesti oludega olid inimesed üsna tuttavad, oldi kursis meil toimuvaga, kuigi läbi propaganda kõverpeegli. Kõige enam tunti muret Eestis elavate muulaste käekäigu üle. Levinud oli kuuldus, et kirju ei lasta üle piiri ja just seetõttu olevat sidemed sugulastega katkenud. Lähemal uurimisel selgus, et kurtjad ise pole juba mitu aastat proovinudki kirja saata, aadresski on meelest läinud. Minu kiri, mille prooviks posti panin, jõudis Zolotaja Nivast Tartusse üheteistkümne päevaga.

Paljud olid nõukogude ajal Eestis sugulastel külas käinud ja rääkisid meelsasti oma seiklustest. Sageli kurdeti: A meid nad seal vihasivad. Olime elektritska pääl, kõik rääkisivad ja midagi ei old. A me kõneleme ju teistmoodi, nad said aru ja küsisid, kust oleme. Siberist. Niikui ära ütlesime, enam ei räägi meiega sõnagi. Paljudel oli ette tulnud juhtumeid, kus vene keeli küsides polnud nad poest kaupa saanud, kuid eestikeelse jutu peale antud soovitu kohe kätte. Üks naine aga rääkis sellise loo: Läksin poodi, seal oli vene müüja, ei saand eesti keelest aru. Tuli eestlane ostma, a see ei osand jälle vene keelt, tahtis õli saada. Müüja ei saand aru. Mina sain, panin ümber, et tema tahab kerassiinu. Müüj hakkas pahandama, et toidupoes nüüd kerassiinu. A ta tahtis poslamaslat. Mina ka ei teand, et eestlastel kõik kerassiin ja poslamasla üks õli on.

Üheks meelisteemaks oli Siberi eesti keele ja meie keele võrdlemine. Zolotaja Niva ja Semjonovka külade elanikud, kes olid lõunaeestilise päritoluga, olid häbelikud: Me ei oska ju rääkimise moodi kõnelda. Ja jälle tuli ridamisi meenutusi. Üks papi oli Eestis käies poes mesimarju näinud ja neid osta soovinud. Müüja öelnud, et ei ole mesimarju. Aga tema ise ju nägi, et on! Näitas siis näpuga. Müüja öelnud: Need ei ole mesimarjad, vaid rosinad." Meiltki uuriti, kas me ikka kõigest aru saame, eriti, kui juhtusime kokku mõne kehvema keeleoskajaga. Meie jaatava vastuse peale kiideti: Nojah, me ikka veel kõneleme, a siin ühed on päris setud, need kõnelevad päris prostoisti: "Üts lats läts."

Omalaadne oli nende jutt nüüd küll. See oli segu esivanemate poolt Eestist kaasa võetud murdekeelest ja Siberis õpitud vene keelest, mis alati ka just puhas kirjakeel ei olnud. Inimesed imestasid ise ka oma rääkimist: Näe, jälle ütlesin vene keeles. Ma tean küll, kuidas ta eesti keeles 
on, aga lipsas vene sõna sisse. A vene keeles kõneldes eesti sõnu vahele ei tule. Jutus esines ka soome- ning lätikeelseidki lausungeid. See segapuder kokku oli meie kõrvale üpris põnev kuulata mõnikord pakkus peamurdmist, teinekord jälle äratundmisrõõmu.

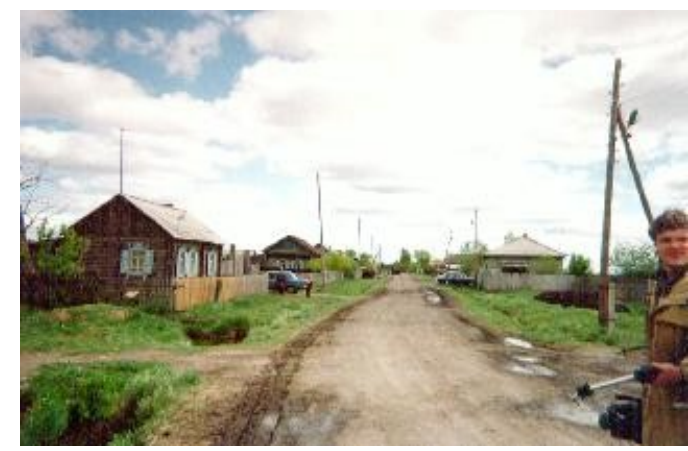

Kovaljova k, Omski obl. Foto A. Korb 1995.

Välisilmelt on külad venepärased, eriti Zolotaja Niva vanem osa, kus elab enamus eestlastest. Majad on ruudukujulise põhiplaaniga. Akende ees on valdavalt sinised luugid, mille avamisega tuleb hoolas olla: Mul alles luugid kinni- nü̈̈d naabrid mõtlevad, et ma nii kaua magan. See oli kivi meie kapsaaeda, sest ajavahe tõttu ei suutnud me õhtul kuidagi uinuda, hommikul aga oli tegu silmade lahti saamisega.

Iga maja juures oli mitu kõrvalehitist ja vähemalt mulle rõõmsa üllatusena vinnaga kaev. Kõikide vitsakeerutajate kurvastuseks pean nentima, et veesoontest ei räägitud meile mitte midagi ning maja või kaevu asupaiga valikuga seotud pärimust seal peaaegu polnudki. Mõni seletas, et no nii sätid, et toas rohkem päikest oleks, ja üks tädi soovitas kaevu ehitada sipelgapesa kohale, kuid üldiselt pomiseti sellestvallast küsimustele midagi ebamäärast ning mittetraditsioonilist vastu.

Algul olid külad sellised, nagu me Eestimaal oleme harjunud nägema, igaüks elas oma krundil. Seoses kollektiviseerimisega hakati maju külla kokku vedama ja nii jäid vanad eluasemed maha. Nendest hoonetest ei ole tänaseks enam midagi järel. Pajatati mitmeid lugusid, kus maja lammutamisel tulnud raha välja ja selgitati, et ehitamise ajal pandud tare nelja nurga alla raha, et majas õnne ja jõukust oleks. Nõukogude aastail olid ebausupidajad põlu all ja nii on paljud ehitusega seotud uskumused unustusehõlma vajunud. Pealegi oli aeg, kui mets oli riigi oma ja nii kallis, et tavaline inimene endale ausal moel majapalke muretseda ei saanud. Hädaga käidi varastamas, kuid said sa siis mingist kombest kinni pidada või seda kõige õigemat puud valida. Vastukaaluks ehitususundi nappusele saime hulgaliselt pajatuselaadseid juttusid metsavargustest.

Zolotaja Nivas on majad seestpoolt valdavalt lubjatud. Seda tööd tehakse igal kevadel ja sügisel ning tingimata vanas kuus. Teised külad, kus viibisime, on kaasaegsema sisustusega, seal on toad pea kõigil tapetseeritud. Nii nagu muudeski valdkondades, olid sisustuseski segunenud eesti ja vene elemendid. Akende ees olid kõigil kardinad, nüüd küll juba poepitsist, kuid mõnedel ka vanema moe järgi käsitsi brodeeritud - "välja löödud", nagu kohalikus keelepruugis öeldi. Voodid olid venepäraselt kõrged ja kohevad, meie neid korralikult üles teha ei osanud, kuid päevatekki ääristas tüüpilise eesti mustriga heegelpits, selline, nagu neid meie memmedegi juures või muuseumides näha võib. Meile seletati, et venelastel on erksamate värvidega tikitud padjapüürid ja käterätikud, eestlastel jälle kas heegeldatud või "välja löödud" pitsiga. Eestlaste kodudes võis kohata nii ühe kui teise moe järgi valmistatud esemeid. Zolotaja Nivas panin õhtuti pea padjale, millele oli tikitud $S$ dobrom utrom, kuid samas oli ka pitsidega püüre. Huvitavalt mõjusid koos moodne Võru mööbel ja traditsiooniline vene ahi; paljudel eestlastel oli toas eesti mööbel.

Uskumusi ja kombeid on hulgaliselt vanematelt päritud, kuid neid on ka venelastelt üle võetud, kusjuures laenuline osa tundub elujõulisem olevat. Eestlaste kombestikku on lisandunud täiesti uus tähtpäev - raditelski den'. See on slaavlaste surnute mälestamise püha, millele eesti pärimuses vastet 
ei ole. Tõsi küll, Setumaas õigeusklikud peavad lihavõttejärgsel nädalal surnute mälestuspäeva raadovitsa, kuid ka seal on see komme venemõjuline. Anu Korb, kes oli juba viiendal Siberi ekspeditsioonil, oli varasematel käikudel sellest tähtpäevast üht-teist küll kuulnud, kuid kuna sellest oli räägitud kui vene pühast, polnud ta sellele suuremat tähelepanu pööranud ja nii ei olnud esialgu täit selgust asja olemusest temalgi. Nüüd oli meil võimalus kõike oma silmaga kaeda. Zolotaja Niva, kus me tol päeval olime, aga ka teiste külade eestlased kinnitasid, et raditelski den' on venelaste püha ja varemalt eestlased seda ei pidanud. Paljud kurtsid, et neile ei meeldi see komme sugugi, kuid püha hommikul pakkisid nemadki oma pirukad, munad, viinapudeli ja muu toidukraami ning seadsid sammud kalmistu poole.

Raditelski den' ei ole kindla kuupäevaga seotud, seda peetakse nädal pärast lihavõtteid. Üldiselt peavad Siberi eestlased pühasid nii uue kui vana kalendri järgi, seega kahel korral. Raditelski den'i kui läbinisti ortodoksset ja ilma eesti vasteta püha peetakse vaid ühel päeval.

Hommikupoolikul läksid kõik surnuaeda. Zolotaja Nivas on kalmistu peateega kaheks jagatud: ühele poole on maetud luterlased, teisele õigeusulised. Eestlaste haudadel on rohkem riste, vene poolel on valdavad raudplaatidest kokku keevitatud püramiidjad mälestusmärgid. Ristide juures hakkas silma, et need on kõik naeltega kokku klopsitud. Eestis üldiselt ei lubata naela risti sisse lüüa, seal seda keeldu nähtavasti ei tuntud; küll aga kinnitas puutööd tundev Eduard Steinbah Ivanovkast, et kirstu sees ei või raudnaela olla. Obeliskidel esines sagedase kaunistuselemendina punane viisnurk, seda ka laste ja mittesõjaväelaste haudadel. Kõik hauaplatsid on ümbritsetud kõrge raudaiaga, mis öeldi vajalik olevat kaitsmaks matmispaika loomade eest. Surnuaial tervikuna aeda ümber ei ole, kalmistuks mõeldud maa-ala on piiratud kraaviga, kui sedagi. Kalmudele on asetatud plekk- ja nailonpärjad, elavaid lilli on vaid üksikutel haudadel näha. Lahkunute mälestuseks küünlaid ei põletata ja talvel haudadel ei käida; sügava lume ning kõrgete aedade tõttu oleks see mõneti ohtlikki.

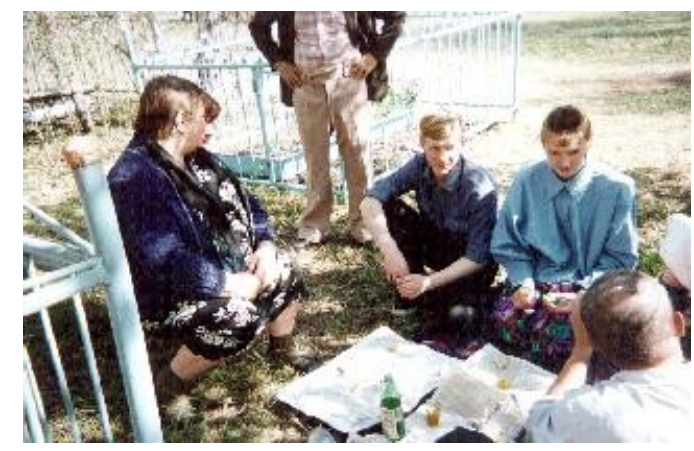

Roditelski den' - surnuaiapüha Zolotaja Niva kalmistul.

Foto A. Korb 1995.
Raditelski den'i tähistasid nii luterlased kui õigeusulised ühtmoodi: perega tuldi hauale, mille kõrval on laud ja pingike (need on seal püsivalt ja kuuluvad matmispaiga juurde; luterlaste poolel on laudu siiski vähem). Kalmudele asetati toitu: värvitud mune, ülepannikooke, poest ostetud küpsiseid, kompvekke ja mida keegi veel vajalikuks pidas; mõni valas hauale ka pegarikese viina. Eestlaste poolel polnud hauapanused eriti rikkalikud, suurem osa toidust pandi mälestajate jaoks lauale. Seal sõid ja jõid lahkunu omaksed ja pakkusid pruukosti ka lähematele tuttavatele, kes mööda minema juhtusid: Tule,võta minu isa mälestuseks! Kõigepealt tuli viinaklaas põhjani juua, siis sai sakuskat peale. Mune ei tohtinud vastu lauda koksida, seda ka kodustel söömadel: Sa sööd ta pealt ja siis pessat ka veel!

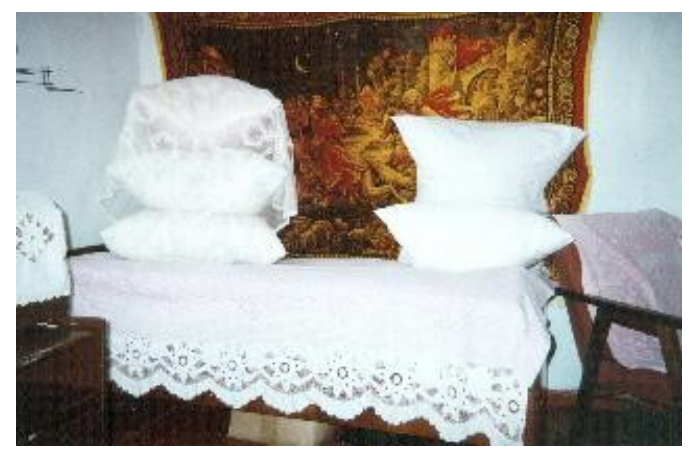

Nurgake Erna Einbaumi toast. Kovaljova k, Omski obl.

Foto A. Korb 1995. 
Leena Illak kutsus mind oma lapselapse hauda vaatama. Kalmul võttis ta ristist kinni ja seisis mõnda aega vaikides. Pärast selgitas ta minu arupärimise peale: Nii ma saan temaga nagu ühendust. Sedasi nägin mitmeid tegevat, sama märkas ka Anu Korb.

Lahkunuid mälestati vaikselt. Mingit valjult itkemist, nagu seda kirjeldab F. F. Bolenev, ei olnud kummalgi poolel; samuti Semjonovkas mitte, kus me polnud küll kõnealusel päeval, vaid 9. mail, mil võidupüha puhul toitudega matussele paminaitama mindi. Kahju, et ei näinud, kuidas raditelski den'i puhtvene külades peetakse, nii et sellekohased võrdlusmaterjalid puuduvad.

Eesti naised laulsid lahkunuid mälestades matuselaule, seda nii Zolotaja Nivas kui Semjonovkas. Need olid nii vaimulikud kui ilmalikud laulud. Laulude valikul lähtutakse eelkõige meloodiast, sõnad on teisejärgulise

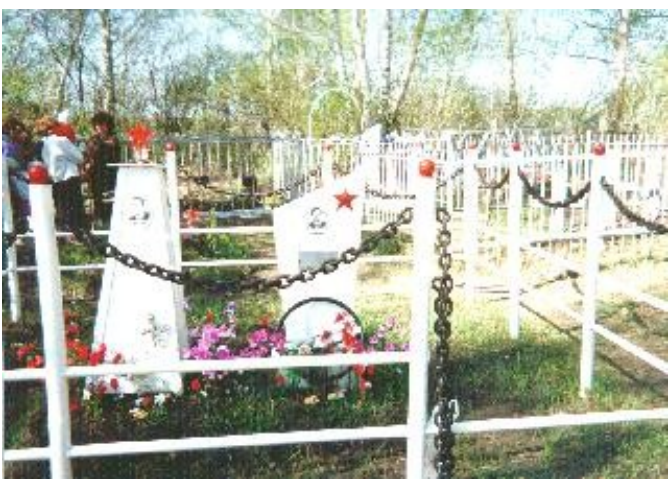

Hauad Zolotaja Niva kalmistul. Foto A. Korb 1995. tähtsusega. Mitmetel olid kaasas laulikud, peast teadsid sõnu väga vähesed. Mehi laulmas ei olnud. Venelased pidavat haudadel laulmist pentsikuks: Teil on lein ja te laulate veel. Eestlaste meelest jälle on see ilus komme. Rosaalia Taits jutustas: Surnuaial laulame alati. Ja surnu juures kodus. Surnu on kodus, siis me muti tuleme kokku, no rohkem omakse ja niimoodi tuleme. Laulikud on kaasas ja laulame; kes nutab, kes laulab, kes kuidas saab, need nii vaheldumisi. Mõnikord ühel ôhtul, vahel kahel, nii kuidas matus on. Küünalt meil ei ole, see on venelastel rohkem. Ja õhtul lähvad kõik koju. Omaksed, kes tahvad, võivad ju või öö läbi istu. Palveraamat on, loetakse palved ärä ja lähme jälle. Surnu juurde ei jäta midagi raamatut. Meil enam neid õigeid trükitud raamatuid polegi, on tetraadidesse ümber kirjutatud.

Kuna lähikonnas pole luterlikku kirikut, siis peab vaimuliku osa täitma keegi kohalikest. Praegu juba aktsepteeritakse ka vene pappi, eriti segaperedes, kuid üldiselt eelistatakse oma traditsioonilist matust. Varem viis seda läbi meesterahvas, nüüd on sobiva meeshinge puudumisel preestri roll naisterahva, Zolotaja Nivas Rosalia Taitsi käes. Ühiskondlik tavatunnetus on selle vastu, nii pahandasid mõnedki, eriti mehed: Kes seda enne näinud on, et naine papp on! Kuid häda ajab härja kaevu ja nii tuleb tunnistada õigeks ka seda, mida aegade jooksul sobimatuks on peetud.

Rosalie Taits ristimib ka lapsi. Kuna vahepealsetel aastatel ristida ei lubatud, kuid vanad tavad ja uskumused tseremooniat ära jätta ka ei lasknud, tehti seda salaja. Tsaariajal käisid õpetajad külades ja just nende initsiatiivil koondati kõik luterlased lähestikku elama - nii oli hingekarjasel lihtsam oma kogudust teenida. Mõistagi ei saanud nõukogude ajal salaja peetavad ristsed suured olla, sinna olid kutsutud ainult lähedased ja kõige usaldatavamad inimesed, seega on unustusehõlma vajunud suured varrupeodki. Praegugi aetakse asja suurema pidulikkuseta. No kui sünnitad ära, said vähe tervemaks, tulid kajatse ja siis kõik naise lätsiva ja siis ristiti ära ka. Üts vanamees olli, too ristis, a nü̈̈ naisterahvas. Praegu pannakse rohkem vene nimesid, kuna lapsed häbenevat eesti omi, mida venelased välja öelda ei oska. Zolotaja Nivas, mis oli kõige venestunum, oli eestlastel endilgi raskusi meie, eriti Indreku nime hääldamisega.

Olgugi, et kõik usuga seotu on üle seitsmekümne aasta põlu all ja lausa karistatav olnud teatakse põhilisi kirikupühasid ikka. Kas tõesti on keelatud vili nii magus või on oma osa siin sellel, et ristiusupühad on ikkagi samad, olgu siis tegemist ükskõik millise kiriku või usulahuga, nii et 
eestlaste ja venelaste mälud on teineteist vastastikku toetanud. Hästi teati ja praegugi peeti kevadpühi, ristipäevi, suvisteid, jõulusid. Rahvuslikuma ilmega pühadest on praegu veel elujõuline jaanipäev, eriti sinna juurde kuuluv tulede tegemine, kuigi see ei olevat enam nii tore kui varemalt, ja sinna juurde kuuluv Jaanide kastmise komme. Kas on siin oma osa sellel, et kastetud Jaan pidi juua pakkuma, teadagi mida? Lõunaeestilistes Zolotaja Nivas ja Semjonovkas käidi veel hiljaaegu maarjapäeval Maarjasid tanutamas ja küpsetati plinasid (ülepannikooke), põhjaeestilistes Ivanovkas ja Kovaljovas teati vaid, et siis minnakse mõne Maarja juurde, kes peab välja tegema (tanutamine on tuntud vaid osas Lõuna-Eestist). Nagu me jutust aru saime, seda päeva enam ei peeta, samuti on mardi-ja kadrisandid ning vastlasõidud veel vaid rahva mälus olemas. Traditsioonilistel külvi- ja karjalaskepäevadel ei ole enam mingit tähtsust. Nende teadjad on juba ammu maamullas ja nõukogude ajal mindi põllule siis, kui partei ja valitsus selleks loa ja käsu andis, olenemata sellest, mida põllumees ise asjast arvas. Pealegi ei ole kõik üksüheselt ülevõetav, sest Eesti ja Siberi kliimad on mõneti erinevad. Praegu, kui kogu elu on pea peale pööratud ja inimestel pole enam millelegi püsivale toetuda, pöördutakse rahvatarkuste juurde tagasi, palju on neist juttu ajakirjanduses. Saa siis aru, mis on inimestel veel esivanemate õpetustest meeles ja mis massimeediast omandatud! Igatahes kuufaase jälgisid nad kõik hoolega ning sellekohaseid teadmisi olid nad kindlasti mõlemast allikast ammutanud.

Keeruline lugu oli heade ja halbade päevadega. Siin olid vastuollu sattunud eesti ja vene uskumused. Inimesed olid segaduses: varem peeti halbadeks päevadeks neid, mil ei olnud hea mingit tööd alustada, esmaspäeva ja reedet, nüüd aga neljapäeva, mis varemalt oli tuntud just hea päevana. Igaks juhuks välditakse nüüd kõiki vähegi kahtlasi päevi ja kõige viljakamaks loetakse teisipäeva, mis on hea päevana tuntud nii eestlastel kui venelastel.

Palju räägiti viimsestpäevast, millest keegi ei tea, millal ta tuleb, kuid mis on kõigi eelduste kohaselt juba üsna lähedal, võib-olla 2000. aastal või veelgi varem. Viimsepäeva märke on ajast aega leitud, kuid ilmselt aitab seekordsele lainele kaasa rahva heaolu üldine vähenemine ning Venemaal valitsevad rasked ja keerulised majandussuhted. Seda võis järeldada ka meile määratud lohutussõnadest: A teil Eestis seda võib-olla ei tulegi: te olete nü̈̈d ju ise ja teil on hoopis teine kultuura ja

elu.

Venemaal on praegu tõeline imearstide, UFO-de ja muude üleloomulike jõudude buum. Fantastilistest juhtumistest ei räägi ainult rahvasuu, need leiavad kajastamist ajalehtedes ja -kirjades, raadios, televisioonis. Päris ise pole keegi tulnukaid näinud, kuid inimesed usuvad siiralt kõike, seda enam, et juurdunud on mõtlemislaad: Kui juba raadios räägitakse ja lehes kirjutatakse, siis peab see tõsi olema. Kirjasõna veenmisjõud on nii tugev, et ei vaevuta mõtlema, mis on belletristika, mis ajalugu. Nii väitis Semjonovka külas üks endine õpetaja, kes oli lugenud Bornhöhed, päris tõsimeeli, et vürst Gabriel päästis Eesti. Meie jahmunud nägusid nähes ning vastuväiteid kuuldes sai ta pahaseks: Kas te siis raamatuid ei loe! Ega muidu raamatus ei kirjutata, ta peab ikka tõsi olema! Igasugune vaidlemine oli mõttetu.

Tshetsheenia sõja puhul põrkusid vene propaganda ja iseseisev mõtlemine. Ajakirjanduses kajastati toimuvat muidugi Venemaale kõige kasulikuma mätta otsast vaadatult, inimeste intuitsioon aga ütles, et midagi on siin viltu. Öeldi,et see on mõttetu sõda, mida poleks maksnud üldse alustada. Oluliseks argumendiks tshetsheenide kaitseks peeti seda, et alles nad olid meiega üks riik, nü̈̈d siis omasid tapavad. Asjaolu, et nende endi lapsed seal sõdivad, kallutas vaekausi Venemaa poolele. Nii peeti kõigis oma hädades on lõppkokkuvõttes tshetsheene endid süüdlasteks. 
Usk "heasse tsaari" avaldus ilmekalt vestlustes Stalinist. Kõik külad olid kannatanud meeletute represseerimiste all, sellest kirjutatakse ka nüüdsetes ajalehtedes. Eduard Steinbah Ivanovkast seletas, et 1937. a. igal hommikul keegi nuttis taga oma ära viidud lähedasi, öösiti pidid inimesed oma elu pärast hirmul olema. Eedistki polnud väljasaatmised mööda läinud, kuid ta kinnitas mitmel korral kangekaelselt: Ega Stalin selles süüdi olnud. Temale anti paberid alla kirjutada, kas tema üldse teadiski, mis paberid need olid. A need siin ise tegivad, need olid kõik oma inimesed, kes seda tegivad. See arvamus oli vääramatu ja seda jagasid pea kõik, äärmisel juhul oldi nõus osa süüd Beriale veeretama.

Oma pikalt kõrvalepõikelt tagasi tulles jätkan ülestunnistusega, et meie Indrekuga lootsime leida nõidu. Tuli välja, et neist on palju ajalehtedes kirjutatud ning teleris näidatud, paljud olid nende jutul käinud, kuid tänapäeva posijatesse suhtuti siiski teatava kahtlusega. Ivanovkas räägiti meile noorest tüdrukust, kes alles mõni aeg tagasi selsavetis vastu olevat võtnud ja pildi järgi kõik haigused ära öelnud, kuid ära ta kadus, ei tea, kas küsis palju või mis seal oli, a nüüd pole teda kaua aega näha olnud. Rohkem on usku nö vanema põlve nõidadesse-tarkadesse, kes tegelevad traditsiooniliselt roosi ja nikastuse ravimisega, oskavad verd seisma panna ja halvast silmast tulnud hädasid arstida. Ükski prohvet pole kuulus omal maal ja nii pidasid sealsed eestlased kangemateks nõidadeks venelasi ja Semjonovkas ka sakslasi. Muidugi oli igas külas olemas ka oma ravitseja. Indrekul ja Anul oli rohkem kokkupuuteid eesti soost külaarstidega, mina rääkisin lühidalt vaid Mati Liisaga ehk Liisa Semjonovaga Ivanovkast. Tema kohta jutustati hulgaliselt lugusid, kuidas ta ühes või teises hädas aidanud, tema oskas ka silmaviga tohterdada. Minule ta oma saladusi ei avaldanud.

Roosi ja nikastust raviti nii, nagu Eestiski seda on tehtud. Paljudel olid endal roosi-, nikastuse-, ja veresõnad olemas, vähemalt olid olnud kuskil kirjas, kui nüüdseks olidki kaduma läinud. Kaemishädasid raviti rohkem vene posijate meetoditega, millest levinumad olid haige pea kohal küünlavaha vette valamine ning pahasilmaveega pesemine. Viimast saadi vee valamisel läbi uksevangu. Kurja silma kardetakse siiamaani. Mulle kurdeti tõsimeeli, et loomal käib tallaja seljas, kuid hädast peaks siiski peatselt jagu saama, sest naabrinaine just eile ütles, mida teha.

Tagantjärele tundub, et kõige vahvamaid usundilisi juttusid kuulsime Semjonovkas ja just Tarast pärit inimestelt. Seekordsel ekspeditsioonil ei räägitud pea üldse lugusid huntidest, karudest, ussidest. Meie küsimistele kosteti vastu, et sealkandis lihtsalt pole selliseid elukaid. Pole tuld - pole suitsu. Väidetavasti ei olevat metsades üldse enam linde-loomi, kõik olevat ära mürgitatud. Linnulaulu ikka

kostus.

Üllatasid Kovaljova laulunaised. Kui mujal lauldi peamiselt kladedest ja üsna nappi repertuaari, siis seal külas ei paistnud lauludele lõppu tulevatki. Lindistasime pea kaks päeva, kusjuures põhiosa laule oli esinejatel peas. Laule ei nimetatud seal pealkirjade järgi, nagu see üldiselt tavaks on, vaid lähtuti sellest, kelle lemmiklaul see on või kes seda eriti hästi oskab. Nii oli "Väikses Rakvere linnas" "Onu Tõnise laul". Loomulikult oli laulu "omanikul" õigus, õigemini küll lausa kohustus oma laul ise üles võtta. Sellest külast saime ka kogu ekspeditsiooniaja haruldasima laulu. See oli uuem rahvalaul teomehest, kes oli Eestist Siberisse asumisele mõistetud. Lindistamine Kovaljova lauljaid ei seganud, ka krõbedamate laulude puhul mitte, sest kui tema (s.t. laul) on Eestist nii Siberisse toodud, siis me saadame tema nii ka tagasi sest ei saa ju sõnu seest välja visata. 
Eestikeelseid laule on saadud mitmel viisil. Kõigepealt võtsid esivanemad, kui nad ümber asusid, kas mälus või kirjapandult oma kodukohas tuntud repertuaari kaasa. Uues kohas, kus saadi kokku teistest paikadest pärinevate eestlastega, täienes lauluvara veelgi. Värskemaid laule lisandus viimase sõja ajal, kui eesti sõdurpoisid olid Siberi külades tervist kosutamas. Oma laulumeistreid pole olnud: Meil nii tarkasid pole old, kes laulu mõistas teta.

Eestist mobiliseeritud paigutati elama kohalike juurde, neid mäletati ja tuletati praegugi veel hea sõnaga meelde. Kuid olles pärit teistest oludest ja teiste kommetega, olid nad kohalikest pisut erinevad, nii et nende omapära üle on veel praegugi mõnus muiata: Olid meil siin eesti poisid. Nad olid sellised kulturna. Pidul üks tuli tantsima võtma, tuli ja kummardas. Ei me läind keegi, pugesime nurka ja itsitasime. See oli nii naljakas, kui ta kummardas!

Et omal ajal olid teistmoodi tantsud kui nüüd, sellest räägiti muidugi ka: Ringi teime ja tantsisime. Igasugu tantsud olid: padespaan ja tusstepp ja valts ja polka ja vastupäeva polka ja... A nü̈d, mis tantsud, nagu teri suruvad uhmris. Kahjuks ei olnud meil aega ega võimalust vaatama minna, kuidas tänapäeval pidu peetakse ja tantsule palutakse.

23. mail alustasime tagasisõitu, et jõuaksime enne viisade kehtivuse lõppu üle piiri. Nimelt ei antud meile Venemaal viibimise luba kauemaks kui kuuks ajaks, põhjusi ei tea. Külades oli valvsaid kodanikke, kes uurisid, kas meil on ikka luba filmida ja lindistada. Viisa oli mõjus paber tõestamaks, et meie tegevus on seaduslik. Zolotaja Nivas oli üks eestisoost mees tõsiselt nördinud: Loll riik, kes niimoodi laseb. Sedasi teie näoga võib igaüks siin spioonitada. Praegu filmite, a pärast saadate meile bomba. Temaga ei õnnestunud ka millestki muust juttu teha: Teist targemadki ei saand minult midagi teada, sulle ei ütle ma ka midagi. Ma juba tean neid värkisi! Võib-olla kahtlustasid meid kõik, ei tea, kuid üldiselt oldi väga külalislahked ja hoolitsevad ning meie dokumente nähes paistsid igasugused kahtlused hajuvat.

Eesti passidel leiti üks oluline puudus olevat: isanime polegi. Tuletasime neile meelde, et teatavasti pole eestlastel kombeks seda kasutada, millega oldi ka nõus, kuid: Kust ma siis tean, kes mu isa on. Arvasime, et võib ju ema käest küsida, kui muidu asjas selgust ei saa. A siis ma olen ju nagu tüdrukulaps, kui kirjas pole...

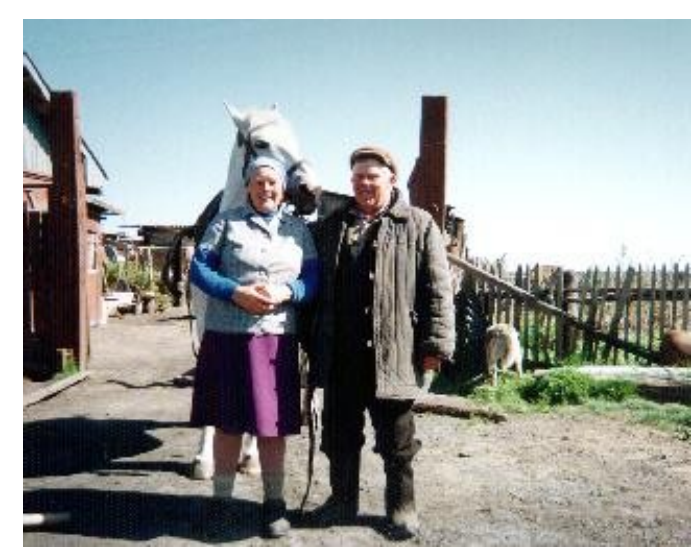

Jutustaja Ermine Brazh abikaasaga oma koduväravas.

Foto I. Kaimer 1995.
Vene rublasid peeti Eesti kroonidest ilusamateks. Meilt küsiti, kelle pildid meie pangatähtedel on ja vastust kuuldes üllatuti: Ah kirjanik? jms. Vene ilusa raha ostujoud on madal. Päts leiba maksis Omski oblastis 600800 rubla, naabritel Novosibirski oblastis 1200 rubla. Nüüd tagantjärgi on mul raske muude hindade kohta midagi täpsemalt öelda, sest kohapealgi oli mul tublisti tegemist, et aru saada, kas öeldud viiega mõeldi viitsada, viit tuhandet või hoopis viitkümmet tuhandet.

Tegelikult polnud olukord Venemaal sugugi nii hirmus, kui teda on tavaks saanud kujutada. Tõsi, maapoodides oli kaupa vähe, kuid tänu valitsevale naturaalmajandusele olid lauad lookas ning kõrgetele hindadele vaatamata (kõrge- 
tele mitte ainult numbriliselt, vaid ka suhtestatult sissetulekuga), suutis igaüks veel kolmele inimesele (st. meile) korraliku laua katta. Samuti polnud kriminaalses mõttes asi nii hull, kui kardetud sai. Üks mu tuttavatest palus mind enne Siberisse sõitu jumalakeeli mitte minna: Nad seal mässavad ja sõdivad ja röövivad - tapavad su maha. Ei tapnud, isegi ei proovinud. Kuu aja jooksul ei tekkinud kordagi seda hirmu ka mitte, kuigi potentsiaalseid tülinorijaid ja purjus inimesi kohtasime kõikjal oma teel ja kohalikud kaebasid, et röövimisi ja tapmisi on nii palju. Muidugi on küla linnast tunduvalt ohutum ja põhiaja veetsime just külades. Vististi on ajapikku kõiki ajaloolisi aspekte arvestades kinnistunud arusaam Venemaast kui koledast kohast, millest üks hullemaid osasid on Siber, külm ja karm paik, kuhu inimesi on ikka saadetud karistust kandma. Keda aga Siberisse saadetud on, see peab ikka hirmus inimene olema! Sealgi pidasid maad saama läinute järglased väljasaadetuid julmemateks, metsikumateks, ohtlikumateks: Neil seal ei lähe ühtki pidu ilma, et kedagi maha ei lööda. Tegelikult tundus kuritegevuse tase kõikjal üsna ühesugune olevat. Eriti vapustavatest tapmistest juttu polnud, küll aga kurdeti varguste rohkuse üle. Samas õigustati: $A$ mis sa teed: raha ei ole, tööd teha ei taha, elada on vaja, viina juua tahad, süüa tahad-pead vargile minema.

Siin ongi paras koht lõpetada Zolotaja Niva memmede tervitustega Eesti vanemale põlvkonnale, nii, nagu mul öelda kästi: Tervitusi siberi karudelt varga kodumaalt!

\section{Fotod}

Anu Korb, Indrek Kaimer, Ell Vahtramäe

Foto 1. Kovaljova k, Omski obl. Foto A. Korb 1995.

Foto 2. Nurgake Erna Einbaumi toast. Kovaljova k, Omski obl. Foto A. Korb 1995.

Foto 3. Roditelski den' - surnuaiapüha Zolotaja Niva kalmistul. Foto A. Korb 1995.

Foto 4. Hauad Zolotaja Niva kalmistul. Foto A. Korb 1995.

Foto 5. Jutustaja Ermine Brazh abikaasaga oma koduväravas. Foto I. Kaimer 1995. 